\title{
Tourism Led-Inflation: A case of Malaysia
}

\author{
M. S. Shaari ${ }^{1 *}$, T. Salha Tunku Ahmad ${ }^{1}$, R. Razali ${ }^{1}$, \\ ${ }^{1}$ School of Business Innovation and Technopreneurship, Universiti Malaysia Perlis (UniMAP), Malaysia
}

\begin{abstract}
The importance of the tourism industry has prevailed among developed and even developing countries. It has been perceived to be an important contribution to economic growth. However, in the proliferation of studies on inflation, information on the extent to which tourism industry able to influence inflation, is still sparse. Therefore, this study embarks on investigating tourism as a potential factor towards inflation. Data on consumer price index and the number of tourist arrival from 1986 until 2014 are used in the analysis. This study adopts a quantitative approach employing the Autoregressive Distributed Lag (ARDL) approach. Several controlled variables such as money supply, economic growth, government expenditure, and interest rate are also included. The results suggest that the tourism industry plays an important role in determining inflation in both short- and long-runs. Therefore, governments should take proactive measures in ascertaining that any expansion of the tourism industry can avert inflation. Keywords: tourism, interest rate, government expenditure, money supply, economic growth
\end{abstract}

\section{Introduction}

Recent efforts to understand the possible impacts of the tourism industry on economic growth has led researchers and policy makers to focus on understanding this industry. Throughout the decades, the literature on tourism sector has fuelled debate on the inextricable association between tourism and the two perspectives of the economy; namely, revenue and employment. Studies in the past decades have shown that countries with a large number of tourist arrival can earn higher revenues, hence boost their economic growth [1-7]. This situation is evidenced in both developed and developing countries. Thus any policy on expansions of the tourism industry can yield good results to the country.

Another aspect of tourism that also attract scholars is the relationship between tourism and employment rate. An increase in the number of tourist arrival can cause the demand for domestic goods and services to rise. Therefore, the supply will simultaneously increase to fulfil the high demand. Hence, people can avail themselves of various job opportunities owing to the higher supply. Thus, a rise in the demand for tourism in that country can prompt an increase in employment [8]. High economic growth caused by tourism implies a lower unemployment rate as evidenced in a study by [9]. This can contribute to a larger consumption of goods and service, causing a higher aggregate demand. As a result, prices of goods will increase, ensuing inflation.

Based on the above review, the tourism sector is perceived to be favourable to the economy [3, 4, 7]. Since many studies show that economic growth is one of the macroeconomic goals, policy makers will formulate policies to ensure positive economic growth. However, high economic growth can be detrimental to the economy as it causes inflation [10]. In this regards, the deleterious effects of the tourism sector on the economy is intriguing. Presumably, the inexorable expansion of the tourism industry can be disadvantageous as it may cause inflation. Tourists will spend their money on hotels, transportations, foods, clothes, etc. This may cause the aggregate demand to escalate, hence, ensuing inflation.

To date, extensive studies have been conducted to investigate the inflation factors. Government policies, money supply, lower interest rate and higher government expenditures are among the factors that potentially impacted economic of one's country [11].

Yet, none has treated tourism as a potential variable with regards to inflation. This factor should be taken into account as many studies also highlighted that tourism can boost economic growth and they proposed various policies on the expansion of the sector. If these policies work in the economy, inflation will surely crop up. Because of this concerns, this study embarks on examining the tourism led-inflation.

\section{Literature Review}

To illuminate the issues on inflation, review on the relevant literature is classified into two perspectives. One is on the predictors of inflation used in the previous studies. Second, is on the findings across the world albeit the similar type of predictors or methods used by researchers. Thus far, the tourism sector is undoubtedly perceived to be favourable to the economy [2, 4]. Parallel with the interest in the economic growth, inflation has become one of the debatable issues in such literature. In studies concerning inflation, predictors such as government policies, money supply, interest rate and government expenditures have been shown to have influenced inflation in one's country.

Most of the studies that use money supplies as inflation predictor, such as those by [12-18], report a positive relationship between money supply and inflation. For instance, [12] found that higher money supply can prompt inflation. This is attributed to the Federal Reserve's policy that attempts to stabilize inflation or increase economic growth by adjusting money supply. Money supply will be increased in order

\footnotetext{
* Corresponding author: shahidanshaari@gmail.com
} 
to ensure positive economic growth. However, a higher money supply can push prices of goods up, thus leading to inflation. This is due to more money in the market.

In the same demeanor, studies on the interest rate [see 13, 14], show that lower rate can increase the number of borrowers, which can cause people to have more money. The higher amount of money people possess, the more money people will spend, thus triggering undesirable inflation. On the contrary, if the interest rate is lower, the inflation can be decreased.

Apart from both factors, government spending can also be a determinant of inflation [19]. Governments need to spend to stimulate the economy and encourage private investments. However, when more money is spent, inflation may be triggered, as there are more investments from the higher government spending. The number of the employed increases and then consumption will hike.

It is noteworthy that, these studies, regardless of the different methods used, have produced consistent findings. In particular, [18] employed the ARDL approach to examine the linkage between money supply and inflation in two groups of countries: high inflation group and low inflation group. Their study found mixed findings between high and low inflations group whereby there is no significant relationship between money supply and inflation in the low inflation group and there is a significant relationship between money supply and inflation in the high inflation group. This finding strongly suggests that inflation is obviously affected by money supply. Another example of studies using similar predictor but different data samples and approach is [17, 15]. They employed ARDL approach and Johansen cointegration approach respectively. Like their counterpart, they also investigated the relationship between money supply and inflation, by applying the methodology to the Malaysia dataset. Although with different samples of data and methods, their findings are consistent with each other, by which relationship between money supply and inflation was evidenced.

Besides studies that use similar predictor with different methods, it is interesting to review the findings on inflation predictors done by researchers in different countries. Using economic growth as the predictor, numerous studies have been conducted to study its' effects on inflation [8, 20, 21]. [20] employed Johansen cointegration to examine the effects of economic growth in Nigeria. The results showed that there is a significant effect of economic growth on inflation in Nigeria. [8] employed Autoregressive Distributed lagged approach to explore the effects of economic growth on inflation in Bangladesh. Data from 1972 to 2012 were analyzed and the results were split into two dimensions; long run and short run. The results consistently showed that economic growth plays an important role in determining inflation in both short and long runs. [21] studied the effects of economic growth on inflation in Nigeria. The study used Multiple Regression Analysis and Variance Inflation Factor (VIF) model to analyze the data from 1970 until 2008. The results showed the existence of a relationship between economic growth and inflation in Nigeria.
Interest rate can also influence inflation across the world. A significant relationship between interest rate and inflation is exemplified in works by [14] in Asia, [22] in Kenya, and [23] in Nigeria. [14] employed the Pooled Mean Group (PMG) and the panel differenced GMM (General Method of Moment) to analyze Asian countries' data from 1985 to 2012 . The results showed that interest rate can significantly affect inflation. [22], using various methods, including Granger causality, correlation and regression, which are different from [14], suggests that there is an existence of a relationship running from interest rate to inflation in Kenya, from 1961 to 2011. While [23] argued that there is no relationship between interest rate and inflation. The study employed the ARDL approach and examined the effects of interest rate on inflation from 1971 to 2010. The findings proved that there is no relationship between interest rate and inflation in Nigeria.

Apart from above factors, the effects of government spending on inflation have also been investigated by previous studies [14, 19, 24]. Some found that government spending is one of the significant determinants of inflation and some found it is not. [19] used Vector Autoregressive Model (VAR) to examine the effects of government spending on inflation in Nigeria from 1970 to 2010 . The study found that government spending is an important factor of inflation in Nigeria. [14] agreed that government spending does really affect inflation. [14] examined the effects in India, Vietnam, and Indonesia using Vector Error Correction Model (VECM). Data from 1970 to 2010 were analyzed and the findings consistently proved that government spending is a significant factor of inflation across the three countries. However, [24] argued that government spending does not have significant influence in Iran. They used Smooth Transition Regression (STR) models transition and quarterly data from 1990 to 2014 were collected. Their findings reveal that government spending does not significantly affect inflation.

\section{Methodology}

This study aims to examine the tourism led-inflation in Malaysia. Data from 1986 to 2014 were collected and analyzed. This study used consumer price index as the proxy for inflation and several controlled variables: consumer price index, money supply (M2) real Gross Domestic Product (GDP), interest rate, and government expenditure. Several tests were conducted in this study such as unit root test, Bound test, long-run and short-run estimations tests using ARDL approach and diagnostic tests. The model specification is as follows:

$\ln \mathrm{CPI}=\alpha+\beta_{1} \ln \mathrm{MS}+\beta_{21} \ln \mathrm{GDP}+\beta_{3} \ln \mathrm{IR}+$ $\beta_{4} \ln \mathrm{TA}+\beta_{5} \ln \mathrm{lE}+\varepsilon$

where:

lnCPI is Log of Consumer Price Index

$\operatorname{lnMS}$ is Log of Money Supply

GDP is Log of Real Gross Domestic Product

IR is Log of Interest Rate 
TA is Log of Tourists Arrival

GE is Log of Government Expenditure

\subsection{Stationary test}

In the analysis of times series data, the unit root test must be conducted to see the stationary of data. Hence, the unit root test based on Augmented Dickey-Fuller (ADF) is performed. Each variable must be estimated at level and first difference. The equation for the unit root is as follows:

$$
\Delta \mathrm{Y}_{\mathrm{t}}=\beta_{1}+\beta_{2} \mathrm{t}+\delta \mathrm{X}_{\mathrm{t}-1}+\alpha \sum_{\mathrm{i}=1}^{\mathrm{p}} \Delta \mathrm{X}_{\mathrm{t}-1}+\mathrm{u}_{\mathrm{t}}
$$

$\mathrm{X}$ indicates the variable while $\mathrm{t}$ is the time trend. $\mathrm{p}$ represents the number of lagged term and $u$ represents the white noise. $\left(\alpha \_1, \alpha \_2, \beta \_1, \ldots \beta \mathrm{m}\right)$ is a set of parameters. If the results of the unit root test show that it is not significant, it means that the data have unit root or are not stationary. If the results show that it is significant, it suggests that the data have no unit root or stationary. Hence, the hypothesis can written as follows:

H_ $0: \delta=0$ (unit root/ non stationary)

$\mathrm{H}_{-} 1: \delta \neq 0$ (no unit root/ stationary)

\subsection{Autoregressive Distributed Lad (ARDL) Model}

This study employs the Error Correction Model based on the ARDL modelling to estimate the relationship between inflation and tourist arrival. This study uses the ARDL model as proposed by Pesaran et al. (2001). Since this study is to examine the effect of tourist arrival on inflation, some control variables such as interest rate, money supply, and government expenditure are also included. In order to estimate the ARDL model, there are three approaches need to be completed. The first step is to estimate a cointegrated relationship among the variables using the following equation:

$$
\begin{aligned}
& \Delta \operatorname{lnCPI}_{\mathrm{t}}=\theta_{1}+\sum_{\mathrm{t}=1}^{\mathrm{p}} \lambda_{1} \Delta \operatorname{lnCPI}_{\mathrm{t}-1}+\sum_{\mathrm{t}=0}^{\mathrm{q}} \lambda_{2} \Delta \operatorname{lnMS}_{\mathrm{t}-1}+ \\
& \sum_{\mathrm{t}=0}^{\mathrm{r}} \lambda_{3} \Delta \operatorname{lnGDP}_{\mathrm{t}-1}+\sum_{\mathrm{t}=0}^{s} \lambda_{4} \Delta \operatorname{lnGE_{\mathrm {t}-1}}+\sum_{\mathrm{t}=0}^{\mathrm{t}} \lambda_{\mathrm{s}} \Delta \ln \operatorname{lR}_{\mathrm{t}-1} \\
& +\sum_{\mathrm{t}=0}^{\mathrm{u}} \lambda_{6} \Delta \ln \mathrm{TA}_{\mathrm{t}-1}+\pi_{1} \operatorname{lnCPI}_{\mathrm{t}-1}+\pi_{2} \operatorname{lnMS}_{\mathrm{t}-1}+ \\
& \pi_{3} \operatorname{lnGDP}_{\mathrm{t}-1}+\pi_{4} \operatorname{lnGE}_{\mathrm{t}-1}+\pi_{5 l} \ln \mathrm{IR}_{\mathrm{t}-1}+\pi_{6} \operatorname{lnTA}_{\mathrm{t}-1}+\mu_{1 \mathrm{t}}
\end{aligned}
$$

where, $\Delta$ is the first differential operator, $(\mathrm{p}, \mathrm{q}, \mathrm{r}, \mathrm{s}, \mathrm{t}, \mathrm{u})$ is the optimum lag and $\mu$ refer to designation. To determine the existence of long run relationship between the variables in the equation (1), the hypothesis is as follows:

$H_{0}$ : There is no cointegration:

$\left(\pi_{1}=\pi_{2}=\pi_{3}=\pi_{4}=\pi_{5}=\pi_{6}=0\right)$

$H_{1}$ : There is cointegration:

$\left(\pi_{1} \neq \pi_{2} \neq \pi_{3} \neq \pi_{4} \neq \pi_{5} \neq \pi_{6} \neq 0\right)$

If the F-statistic value is larger than upper bound critical value, it can be concluded that there is an existence in cointegration between the variables. If the F-statistic value is less than the lower bound critical value, then null hypothesis cannot be rejected. If the F-statistic value is between the upper bound and lower bound critical value, so the existence of cointegration cannot be determined. If there is an existence of cointegration, next step is to estimate the long-run relationship using the following equation:

$$
\begin{aligned}
& \ln C P I_{t}=\theta_{11}+\sum_{i=1}^{p} \pi_{11} \ln C P I_{t-i}+\sum_{i=0}^{q} \pi_{22} \ln M 3_{t-i}+ \\
& \sum_{i=0}^{r} \pi_{33} \ln G D P_{t-i}+\sum_{i=0}^{s} \pi_{44} \ln G E_{t-i}+\sum_{i=0}^{t} \pi_{55} \ln I R_{t-i}+ \\
& \sum_{i=0}^{u} \pi_{66} \ln T A_{t-i}+\mu_{11 t}
\end{aligned}
$$

The final step, the short run ARDL model is estimated by including the error correction terms (ECT). The shortrun estimation is depicted via an expression as follow:

$$
\begin{aligned}
& \Delta \operatorname{lnCPI}_{\mathrm{t}}=\theta_{111}+\sum_{\mathrm{t}=1}^{\mathrm{p}} \lambda_{111} \Delta \operatorname{lnCPI} \mathrm{I}_{\mathrm{t}-1}+\sum_{\mathrm{t}=1}^{\mathrm{q}} \lambda_{222} \Delta \operatorname{lnMS}_{\mathrm{t}-1} \\
& +\sum_{\mathrm{t}=1}^{\mathrm{r}} \lambda_{333} \Delta \operatorname{lngDP} \mathrm{t}_{\mathrm{t}-1}+\sum_{\mathrm{t}=1}^{\mathrm{s}} \lambda_{444} \Delta \ln \mathrm{lE}_{\mathrm{t}-1}+ \\
& \sum_{\mathrm{t}=1}^{\mathrm{t}} \lambda_{555} \Delta \operatorname{lnIR}_{\mathrm{t}-1}+\mu_{111 \mathrm{t}}
\end{aligned}
$$

\section{Results}

The unit root test was conducted to determine the stationary properties of the time series data. This test was based on the Augmented Dickey-fuller (ADF) approach. The results were divided into two levels: level with trends and level without trends. Table 4.1 shows the results of the unit root test. The results show that all the variables are significant at first difference. It indicates that the variables are stationary at first difference. Based on the results, the ARDL test can be conducted. 
Table 4.1: Unit Root Test Results.

\begin{tabular}{|c|c|c|c|c|}
\hline & \multicolumn{2}{|l|}{ Intercept } & \multicolumn{2}{l|}{ Intercept and trend } \\
\cline { 2 - 5 } & Level & $\begin{array}{l}\mathbf{1}^{\text {st }} \\
\text { difference }\end{array}$ & Level & $\begin{array}{l}\mathbf{1}^{\text {st }} \\
\text { difference }\end{array}$ \\
\hline CPI & $-4.19^{*}$ & $-5.93^{*}$ & $-4.21^{* *}$ & $-5.86^{*}$ \\
\hline MS & -2.36 & $-2.89^{* *}$ & -1.95 & $-3.68^{* *}$ \\
\hline GDP & -1.04 & $-5.03^{*}$ & -2.23 & $-5.00^{*}$ \\
\hline GE & -0.38 & $-5.31^{*}$ & -2.51 & $-4.66^{*}$ \\
\hline IR & $-6.27^{*}$ & $-8.00^{*}$ & $-7.43^{*}$ & $-7.836^{*}$ \\
\hline TA & 0.01 & $-4.81^{*}$ & -2.04 & $-4.82^{*}$ \\
\hline
\end{tabular}

Note: $*, * *$, and $* * *$ significant at $1 \%, 5 \%$ and $10 \%$ significant respectively.

The Bound test was conducted and the results were recorded in Table 4.2. The results show that the value of F-statistics is 5.167 which is larger than the value of upper bound at a significant level of $1 \%$. Therefore, it can be concluded that an estimation of a long-run relationship can be performed.

Table 4.2 Bound Test for the Existence of a Long Run Relationship

\begin{tabular}{|c|c|c|}
\hline \multicolumn{3}{|c|}{ F-statistic } \\
\hline \multicolumn{3}{|c|}{5.167021} \\
\hline \multicolumn{3}{|c|}{ Critical value } \\
\hline Significance & 10 Bound & l1 Bound \\
\hline $1 \%$ & 3.41 & 4.68 \\
\hline $2.5 \%$ & 2.96 & 4.18 \\
\hline $5 \%$ & 2.62 & 3.79 \\
\hline $10 \%$ & 2.26 & 3.35 \\
\hline
\end{tabular}

Table 4.3 shows the results of the estimated long run coefficient. The results suggest that money supply can negatively affect inflation at a significant level of $1 \%$. Therefore, a $1 \%$ increase in money supply can cause inflation to increase by $17 \%$ in the long run. Based on the results, it may suggest that GDP does not affect inflation in the long run as the value of probability is 0.3182 and it is not significant at any level. Apart from that, government expenditure can positively affect inflation as it is significant at $1 \%$. Hence, a rise of $1 \%$ in government expenditure can increase by $25.25 \%$ in the long run. The results also indicate interest rate can trigger inflation as it is significant at $1 \%$. This implies that a $1 \%$ rise in interest rate can prompt inflation to rise by $0.88 \%$ in the long run. The results also suggest that tourist arrival can significantly affect inflation as it is significant at $1 \%$. Therefore, an increase in $1 \%$ tourist arrival will lead to an increase of $14.87 \%$ in inflation. The constant value in this result is also significant at 5\% with a coefficient value of 18.1780 .
Table 4.3 Estimated Long Run Coefficient using the ARDL Approach

\begin{tabular}{|c|c|c|c|}
\hline Variable & Coefficient & $\begin{array}{c}\text { Standard } \\
\text { Error }\end{array}$ & Probability \\
\hline MS & 17.16 & 4.93 & $(0.00)^{*}$ \\
\hline GDP & 5.49 & 5.16 & $(0.31)$ \\
\hline GE & 23.25 & 6.02 & $(0.00)^{*}$ \\
\hline IR & 0.88 & 0.22 & $(0.00)^{*}$ \\
\hline TA & 14.87 & 3.91 & $(0.00)^{*}$ \\
\hline C & 18.18 & 6.76 & $(0.02)^{* *}$ \\
\hline
\end{tabular}

Notes $*$, and $* *$ indicate significant at $1 \%$ and $5 \%$ significant level.

Table 4.4 shows the result of the estimated short-run coefficients. The results indicate that money supply significantly affect inflation and it is significant at $1 \%$. Therefore, a $1 \%$ increase in money supply can cause inflation to increase by $14.9 \%$ in the short run. The results also suggest that GDP and government expenditure do not have any influence on inflation in the short run. The interest rate is found to be connected with inflation as the results show that it is significant at $1 \%$. It implies that an increase of $1 \%$ in interest rate can soar by $0.59 \%$ in the short run. Other than that, tourist arrival can have an effect on inflation as it is significant at 5\%. This suggests that if tourist arrival goes up by $1 \%$, inflation will surge by $3.5 \%$.

Table 4.4 Estimated Short-run Coefficients Using the ARDL approach

\begin{tabular}{|c|c|c|c|}
\hline Variable & Coefficient & $\begin{array}{c}\text { Standard } \\
\text { Error }\end{array}$ & Probability \\
\hline dMS & 14.90 & 2.70 & $0.00^{*}$ \\
\hline dGDP & 2.73 & 7.09 & 0.71 \\
\hline DGE & 7.17 & 6.37 & 0.29 \\
\hline dIR & 0.59 & 0.13 & $0.00^{*}$ \\
\hline dTA & 3.56 & 1.28 & $0.02^{* *}$ \\
\hline
\end{tabular}

Notes $*$ and $* *$ indicates significant at $1 \%$ and $5 \%$ level respectively.

Table 4.5 shows the results of the diagnostic tests. These tests are to check the goodness of the ARDL model. The Breusch-Godfrey Serial Correlation test, the Ramsey RESET stability test and the ARCH test were conducted. The results show that they are all not significant at any level. Therefore, it can be concluded that no evidence of autocorrelation, serial correlation and heteroscedasticity.

Table 4.5 Diagnostic Tests

\begin{tabular}{|l|l|}
\hline Test statistic & F-statistic (Probability) \\
\hline $\begin{array}{l}\text { A: Breusch-Godfrey } \\
\text { Serial Correlation }\end{array}$ & $0.49(0.63)$ \\
\hline $\begin{array}{l}\text { B: Ramsey RESET } \\
\text { stability }\end{array}$ & $0.12(0.73)$ \\
\hline C: ARCH & $0.01(0.91)$ \\
\hline
\end{tabular}


In order to ensure the stability of the variables, the cumulative sum (CUSUM) and cumulative sum of squares (CUSUMQ) tests were conducted. Figure 4.6 shows the results of CUSUM and CUSUMQ. The results show that the plots are both located within the margins where both straight lines denote the critical bound at $5 \%$ significance level, meaning that this model is good. Therefore, it can be observed that there is a long run coefficient stability in the variables.

Figure 4.6 CUSUM and CUSUMQ
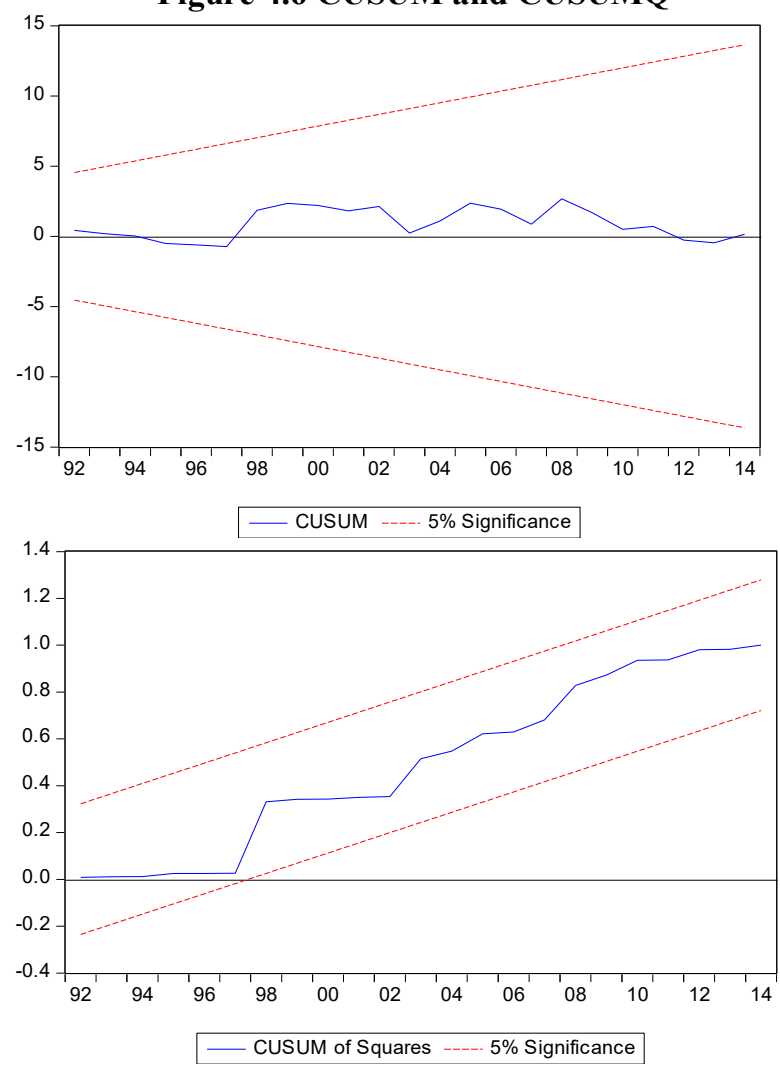

\section{Conclusions}

This study aims to investigate the tourism ledinflation in Malaysia from 1986 to 2014. The unit root tests were conducted and the results show that most of the variables are non-stationary at level and stationary at first difference. Then, the Bound test was conducted and the results show that there is a cointegration. The longrun estimation using the ARDL approach was carried out and the results show that money supply, interest rate, movement expenditure, and tourist arrival can positively affect inflation in the long run. However, economic growth does not have any effect on inflation. Other than that, the short-run estimation using the ARDL approach was also performed and the results indicate that money supply, interest rate, and tourist arrival can influence inflation in the short run. Nevertheless, government expenditure and economic growth do not have any significant effect on inflation.

This study can be instrumental in the formulation of policies on tourist arrival in order to avert inflation. Inflation is one of the macroeconomic problems that should be controlled by all countries. Since an expansion of the tourism industry can trigger inflation in both short- and long-runs, the government should take possible careful measures to prevent inexorable expansion of the industry, while elevating its potential as country's economic booster.

\section{References}

1. Lee, C. C. \& Chang, C. P. Tourism development and economic growth: A closer look at panels, Tourism Management, 29, 180-192. (2008).

2. Katircioglu, S. T. Revisiting the tourism-led-growth hypothesis for Turkey using the bounds test and Johansen approach for co-integration. Tourism Management, 30, 17-20. (2009).

3. Payne, J.E., \& Mervar, A. The tourism growth nexus in Croatia. Tourism Economics, 16(4), 10891094. (2010).

4. Seetanah, B. Assessing the dynamic economic impact of tourism for island economies. Annals of Tourism Research, 38(1), 291-308. (2011).

5. Lee, J.W. and Brahmasrene, T. Investigating the Influence of Tourism on Economic Growth and Carbon Emissions: Evidence from Panel Analysis of the European Union. Tourism Management, 38, 6976. (2013).

6. Pablo-Romero, M.P., \& Molina, J.A. Tourism and economic growth: A review of empirical literature. Tourism Management Perspectives, 8, 28-41. (2013).

7. Salmani, B., Panahi, H., \& Razzaghi, S. Assessing the dynamic economic impact of tourism for OIC members. World Applied Sciences Journal, 32(6), 1098-1105. (2014).

8. Inchausti-Sintes F. Tourism: Economic growth, employment and Dutch disease. Annals of Tourism Research, 54, 172-189. (2015).

9. Jebabli, I., Arouri, M., \& Teulon, F. On the effects of world stock market and oil price shocks on food prices: An empirical investigation based on TVPVAR models with stochastic volatility. Energy Economics, 45, 66-98. (2014).

10. Uddin, S., Chowdhury, M.N.M., \& Hossain, M.A. Determinants of inflation in Bangladesh: An econometric investigation. Journal of World Economic Research, 3(6), 83-94. (2014).

11. Khan, R.E.A. \& Gill, A.R. Determinants of Inflation: A Case of Pakistan (1970-2007). Journal of Economics, 1 (1). 45-51. (2010).

12. Akinbobola T.O. The dynamics of money supply, exchange rate and inflation in Nigeria. Journal of Applied Finance \& Banking, 2(4), 117-141. (2012).

13. Anari A. and Kolari J. Dynamics of interest and inflation rates. Journal of Empirical Finance, 39(December 2016), 129-144. (2016) 
14. Nguyen V.B. Effects of Fiscal and Money M2 Supply on inflation: Evidence from selected economies of Asia. Journal of Economics, Finance and Administrative Science, 20(38), 49-53. (2015)

15. Khai, T.M. Determinants of inflation in Malaysia 1981-2010. MBA management project, Universiti Sains Malaysia. (2011).

16. Basher, S. A., \& Elsamadisy, E. M., (2012). Country heterogeneity and long-run determinants of inflation in the gulf Arab states. OPEC Energy Review, 36(2) 170-203.

17. Hashim, M.J., Osman, I., \& Elias, N.L. The determinants of inflation in Malaysia. 3rd International Conference on Accounting, Business and Economics (ICABEC2014) (2014).

18. Lim, Y.C., \& Sek, S.K. An examination on the determinants of inflation. Journal of Economics, Business and Management, 3(7). (2015).

19. Olayungbo, D.O. Government spending and inflation in Nigeria: An Asymmetry Causality Test, International Journal of Humanities and Management Sciences, 1(4). (2013)
20. Sictus, A. Agricultural share of the gross domestic product and it implication to rural areas. International Journal of Social Economics, 226-238. (2010).

21. Odusanya, I. A., \& Atanda, A. A. Analysis of inflation and its determinants in Nigeria. Pakistan Journal of Social Sciences, 7(2), 97-100. (2010).

22. Mmasi, B.S. An investigation of the relationship between interest rate and inflation in Kenya. MBA thesis, College of Humanities and Social Sciences (CHSS). (2013).

23. Ebiringa, O.T., \& Anyaogu, N.B. Exchange rate, inflation and interest rates relationships: An Autoregressive Distributed Lag Analysis. Journal of Economics and Development Studies, 2(2), 263279. (2014).

24. Mehrara, M., Soufiani, M.B., \& Rezaei, S. The Impact of Government Spending on Inflation through the Inflationary Environment, STR approach. World Scientific News. 37, 153-167. (2016) 